\title{
Chair of GMO panel resigns over maize
}

[PARIS] One of France's leading human geneticists has resigned as chairman of the committee that advises the French government on genetically modified organisms (GMOs), claiming that a recent decision by the French government to ban the cultivation of a transgenic maize has made his job impossible.

Axel Kahn, director of the INSERM Laboratory of Research on Genetics and Molecular Pathology at the Cochin Institute of Molecular Genetics in Paris, and chairman of the Biomolecular Engineering Commission, claims that the decision is inconsistent with an earlier decision by the government to seek permission for the import of the maize from the United States and the sale of the resulting crops.

Following a meeting of the French cabinet last week, Alain Juppé, the prime minister, announced that farmers would now be forbidden to grow the maize, which is produced in the United States by Ciba-Geigy, and was approved for import by the European Commission in December.

The modified maize contains a gene from the bacterium Bacillus thuringiensis, which makes it resistant to the European corn borer, a pest responsible for the loss of 5 to 10 per cent of the annual harvest. The maize also contains a herbicide-resistant gene, and a marker gene conferring resistance to the antibiotic ampicillin.

It was the French government that asked the European Commission (EC) in $1994-$ after the Biomolecular Engineering Commission had approved the dossier - to approve marketing of the maize throughout the European Union. France continued to seek permission up to the time the commission finally approved import of the maize last December.

Furthermore the main benefits of the maize are to farmers, who will now be denied use of the seed. At the same time, the government earlier this month authorized consumption of the maize by animals and humans, apparently indicating that it feels that the environmental risks of the maize are greater than any risk to either human or animal health.

This conflicts with the outcome of two years of debate surrounding the approval of the maize within the European Union. Controversy centred not on environmental concerns but on the potential risks to humans of the maize's antibiotic-resistance gene which some - in particular the UK Advisory Committee on Novel Foods and Processes - argued might pass to bacteria in the gut of livestock and from there to humans (see Nature 383, 564, 1996).

Although transgenic plants in general raise environmental concerns, such as the risk of the transfer of herbicide-resistance genes to weeds, Ciba-Geigy's maize is widely considered to be free of such risks, as it does not cross with native European plants.

Juppés decision appears to have been the result not of any new detailed study of the environmental risks of the maize but of a spontaneous response to a statement at the cabinet meeting by Corinne Lepage, the minister of environment, questioning the environmental safety of GMOs, and asking for a decision on the cultivation of the modified maize to be postponed.

The government goal is widely seen as an attempt to placate consumer and environmental organizations in the wake of the bovine spongiform encephalopathy (BSE) crisis. In a statement issued after the meeting, the environment ministry applauded the government's "concern to apply the precautionary principle [in the light of the environmental risks of GMOs]".

Kahn says that the decision has "left him with no choice but to resign". Although the Biomolecular Engineering Commission acts only as an advisory body, the government had asked it to represent France officially in defending the Ciba-Geigy application in Brussels.

The EC's approval of the maize was a "great success" for France, says Kahn, arguing that the government's new decision has destroyed both its own credibility and that of the Biomolecular Engineering Commission in international discussions. "If I were to go to a meeting in Brussels in future, people are going to ask 'will what Mr Kahn says be contradicted by his government tomorrow?"', he says. "I wouldn't have any credibility."

Kahn acknowledges that his resignation from the Biomolecular Engineering Commission, which he has chaired since its creation in 1986, has thrown France's well established system for approving GMOs into "crisis". It has authorized more than 450 field trials of transgenic plants, more than the total of all other European countries combined, and second only to the United States.

But he says that resigning was the "only honourable way" of forcing all those involved to clarify a "totally incoherent situation". The government has only two ways out, he asserts. Either it should concede that the "democratic debate" over GMOs in France now requires a complete review of the maize dossier, in which case imports should be banned, or it should revoke its ban on cultivation of the maize.

Kahn argues that the government's U-turn is also symptomatic of the disarray in scientific advisory systems that has been prompted by a series of scandals, including BSE and the contaminated blood and growth hormone affairs.

Being an expert is "extremely difficult" at present, says Kahn, arguing that the public's suspicion about the independence of experts has never been greater. The maize controversy may be an excellent opportunity to test in France the idea of whether lay consensus conferences can make progress in reconciling scientific advice, public opinion and political choices, he says.

Kahn, who has a high profile in public debates on scientific issues in France, says that he now intends to concentrate his public activities on the "combat" against what he claims is the most serious threat facing society - "scientific racism and genetic determinism based on an erroneous concept of genetics". An emerging convergence between genetic reductionism, ultraliberal economics and individualist ideologies raises an "enormous risk" that history is set to repeat itself, he warns. "It is very important to engage in this battle".

DeclanButler

\section{Three share Australian prize for telecoms}

[SYDNEY] The Australia Prize, worth $A \$ 300,000$ (US\$375,000) and awarded this year for research work in the field of telecommunications, has been shared by three researchers covering the range from theory to application.

At the fundamental end of the spectrum, Allan Snyder (centre), a US researcher at the Australian National University in Canberra, was rewarded for his theory of guiding light, the blueprint for the development of optical fibres. Rodney Tucker (left), an electrical engineer at the University of Melbourne, was recognized for developing a tenfold expansion in the capacity of optical fibres.

Gottfried Ungerboeck (right), of IBM Laboratories, Zurich, Switzerland, received

\section{IMAGE UNAVAILABLE FOR COPYRIGHT REASONS}

the award for trellis-coded modulation, the industry standard which made possible high-speed modems.

In presenting the prize last week, John Howard, the prime minister, said his government was committed "very strongly to the central role of science and technology in the future of Australia". 